\title{
Anti-Inflammatory and Antioxidant Effect of Astaxanthin Derived from Microalgae
}

Tae Won Kwak', Ji Young Cha', Chul Won $\mathrm{Lee}^{2}$ and Young Min Kim³, Byung Hong Yoo ${ }^{3}$, Sung Gu $\mathrm{Kim}^{3}$, Jong-Myoung $\mathrm{Kim}^{4}$, Seongha Park ${ }^{1}$ and Won Gun $\mathrm{An}^{1,2}$

${ }^{1}$ School of Korean Medicine, Pusan National University, Yangsan 626-870, Korea

${ }^{2}$ Institute of Marine BioTechnology, Pusan National University, Busan 609-735, Korea

${ }^{3}$ Bio Port Korea, Inc., Busan 619-912, Korea

${ }^{4}$ College of Fisheries Science, Pukyong National University, Busan 608-737, Korea

Received May 31, 2011 /Revised June 28, 2011 /Accepted July 8, 2011

\begin{abstract}
Astaxanthin (ATX) is a red-orange carotenoid pigment that occurs naturally in a wide variety of living organisms. In this study we investigated the inhibitory effects of ATX on the induction of inducible nitric oxide synthase (iNOS), nitric oxide (NO), proinflammatory cytokines, nuclear factor-kappa B (NF-kB) and reactive oxygen species (ROS) in lipopolysaccharide (LPS)-stimulated RAW264.7 cells. In addition, we tested the superoxide radical scavenging activity of ATX by scavenging assay. iNOS and NF- $k B$ expressions were determined by immunoblot analysis. Interleukin (IL)- 6 and tumour necrosis factor- $a$ (TNF- $a$ ) were assayed by ELISA. NO production was monitored by measuring the amount of nitrite. ROS was examined by using the 2', 7'-Dichlorodihydrofluorescin diacetate (DCFH-DA) method. At a concentration of $100 \mu \mathrm{M}$, ATX inhibited the expression level of LPS-induced NF-kB, as well as the production of LPS-induced NO and proinflammatory cytokines (IL-6 and TNF-a), by suppressing iNOS expression. In particular, the maximal inhibition rate of IL-6 and TNF-a production by ATX $(100 \mu \mathrm{M})$ was $65.2 \%$ and $21.2 \%$, respectively. In addition, ATX inhibited the LPS-induced transcriptional activity of NF- $\mathrm{kB}$, and this was associated with suppressing the translocations of NF- $\mathrm{kB}$ from the cytosol to the nucleus. Moreover, at various concentrations $(25-100 \mu \mathrm{M})$, ATX inhibited the intracellular level of ROS. At a concentration of $5 \mathrm{mg} / \mathrm{ml}$, the superoxide radical scavenging activity of ATX was 1.33 times higher than a-tocopherol of the same concentration. These results showed that ATX inhibited the expression of iNOS and the production of NO and proinflammatory cytokines resulting from ROS production and NF-kB activation in macrophages. Furthermore, ATX was found to be more effective in superoxide radical scavenging activities compared to a-tocopherol. These findings are expected to strengthen the position of ATX as anti-inflammatory medicine and antioxidant.
\end{abstract}

Key words : Astaxanthin, anti-inflammatory effect, nuclear factor-kappa B, interleukin-6, superoxide radical scavenging activity

\section{서 론}

염증은 물리·화학적인 독성자극이나 미생물의 독성물질에 의해 신체국소에서 발생되는 상해를 제거하여 본 상태로 회복 시키려는 유기체의 반응이다. 염증반응에서 자극은 직접 생체 에 작용하여 손상을 주기도 하지만, 대개 간접적으로 내인성 화학전달물질을 통해 국소의 혈관이나 세포에 전달되며, 이로 말미암아 관절염, 천식, 자가면역질환 그리고 동맥경화증과 같은 다양한 질병이 발생한다[12,29]. 이러한 질병의 원인이 Reactive Oxygen Species (ROS) 생성에 관련이 있다는 사실이 밝혀짐에 따라 염증과 ROS와의 연계성에 대한 연구가 활발히 이루어지고 있다[22]. Miesel 등[25]은 매우 독성이 강한 산화 제인 superoxide를 포함하는 ROS는 염증기간 동안에 조직 손

*Corresponding author

Tel : +82-51-510-8455, Fax : +82-51-510-8437

E-mail : wgan@pusan.ac.kr
상을 직접 초래할 수 있다고 보고하였다. 이러한 조직손상이 암의 발생 및 악성종양화와 관련이 있다.

최근 연구결과에 따르면 세포내 면역반응의 전사인자인 nuclear factor-kappa B (NF-kB)는 염증질환, 암의 발생 및 전 이, 악성종양화, 자가면역질환 등에 중심적인 역할을 하는 것 이 밝혀져 염증 및 암 치료의 중심 target molecule로 대두되고 있다. NF-kB는 세포에 가해지는 스트레스에 대한 면역응답을 매개하는 전사인자임과 동시에 면역체계의 형성과정과 장기 발육에도 깊이 관여하고 있으며 ROS 및 독소물질 등에 의해 과다 활성화되면 면역과민반응과 함께 류마티스관절염, 각종 알레르기성 염증, 자가면역질환 등의 염증성질환과 다양한 암 을 유발시키는 것으로 알려져 있다[9,16,21].

미세조류 중 Haematococcus pluvialis가 생산하는 생리활성 물질인 astaxanthin (ATX, 3,3'-dihydroxy- $\beta$, $\beta^{\prime}$-carotene-4$4^{\prime}$-dione)은 자연계에 널리 분포되어 있는 ketocarotenoid로 polysoprenoid와 oxygen quenching 기능을 가진 benzenoid 
ring의 결합체이며[31], 물고기와 동물의 음식물 속에 들어있 는 색소의 원료일 뿐만 아니라, vitamin E와 $\beta$-carotene 보다 강한 free radical 항산화활성을 가진 잠재력이 있는 물질이다 $[10,18]$. 또한, 이 생리활성물질은 과산화상태에서 막의 phospholipid와 다른 지질들을 보호하는 기능을 가진 우수한 물질 로 알려져 있으며[26,27], 특히 이 물질의 항산화작용은 singlet oxygen 및 free radical을 소거함으로 항암 및 면역기능활성에 효과가 있는 것으로 보고되고 있다[3,4,17, 19,34]. ATX에 대한 연구보고는 많으나, 항염 및 항산화작용에 대한 명료한 기작 및 효과를 증명하는 결과는 아직도 미미한 실정이다. 따라서, 본 연구에서는 미세조류로부터 유래한 ATX를 이용하여 항염 및 항산화작용에 대한 기작 및 효과를 검증하고, 류마티스관 절염, 알러지, 천식, 암 등의 주요조절인자인 NF-kB의 활성 억제를 검증하여 항염증제, 항산화제 및 항암치료제로서의 가 능성을 타진하고자 한다.

\section{재료 및 방법}

\section{ATX의 제조}

ATX의 생산을 위해 기본적으로 $\mathrm{NB} / 2$ 배지(효율적인 성장 을 위해 다른 질소원을 추가적으로 첨가)에서 Haematococcus pluvialis CCAP-34/1F 균주를 배양하였으며, 다른 배양조건으 로는 $25^{\circ} \mathrm{C}, 160 \mathrm{rpm}, 10 \%$ inoculum, 초기 $\mathrm{pH}$ 는 7.0 , 조도는 3,000-3,500 lux를 선정하였다. ATX의 생산유도를 위해 vegetative cell로부터 cyst cell을 만드는 배양조건을 $23^{\circ} \mathrm{C}, 150$ $\mathrm{rpm}, 14,000 \mathrm{lux}$ 로 하여 15 일째 붉은 색의 배양액을 확인하였 다. 균체를 원심분리하여 균을 모으고 $25 \mathrm{ml}$ 의 아세톤을 첨가 하여 파쇄한 후 냉각추출을 반복하였다. 그 후, 감압농축을 하였고 n-Hexane으로 다시 추출한 후, 물로 3 번 세척하였고, sodium sulfate anhydrous를 이용하여 잔류수분을 제거한 후 $\mathrm{ATX}$ 추출물을 제조하였다. 본 실험에서는 ATX를 $0.01 \%$ dimethyl sulphoxide (DMSO)에 용해하여 사용하였다.

\section{시약}

Dulbecco's modified Eagle's medium (DMEM)은 Hyclone (Thermo Scientific Inc., Bremen, Germany)에서 구입하였고, fetal bovine serum (FBS)은 Sigma Aldrich Co. (St. Louis, $\mathrm{MO}, \mathrm{USA}$ )로부터, penicillin 및 streptomycin은 Gibco/BRL (Grand Island, NY)에서 구입하였다. Anti-iNOS monoclonal antibody는 Calbiochem (San Diego, Calif.)에서, Anti- $\beta$-actin monoclonal antibody는 Sigma Aldrich Co. 로부터 구입하였 다. Anti-NF-kB p65 monoclonal antibodies와 peroxidase-conjugated secondary antibody는 Santa Cruz Biotechnology, Inc. (Santa Cruz, CA, USA)로부터 구입하였 고, interleukin (IL)-6 및 tumour necrosis factor-a (TNF-a) ELISA Kits는 Pierce Endogen (Rockford, IL, USA)에서
Promega luciferase assay system은 Promega (Madison, CA, USA)로부터 구입하였고, 3-(4,5-dimethylthiazol-2-yl)-2,5-diphenyl tetrazolium bromide (MTT), sulfanilamide, lipopolysaccharide (LPS) 및 다른 모든 시약들은 Sigma Aldrich $\mathrm{Co}$.에서 구입하였다.

\section{세포배양}

대식세포주인 RAW264.7 cell은 한국세포주은행(Seoul, Korea)에서 구입하였으며, NF-kB 전사활성을 측정하기 위하 여 NF-kB reporter construct로 transfection된 RAW264.7 cell (이하 NGL cell)은 주명수 교수로부터 분양 받아 사용하였다. Dulbecco's modified Eagle's medium (DMEM)에 10\% fetal bovine serum (FBS), $100 \mathrm{U} / \mathrm{ml}$ penicillin 및 $100 \mu \mathrm{g} / \mathrm{ml}$ streptomycin을 혼합한 배지를 사용하여 $37^{\circ} \mathrm{C}, 5 \% \mathrm{CO}_{2}$ incubator 에서 세포를 배양하여 실험에 이용하였다.

\section{세포 생존율 측정}

RAW264.7 cell을 96 well plate에 $5 \times 10^{4}$ cells/well로 분주 하여 16시간 배양한 후, ATX를 농도별 $(25-100 \mu \mathrm{M})$ 로 처리하 여 1시간 동안 배양하였다. 그 후, lipopolysaccharide (LPS)를 처리하여 $37^{\circ} \mathrm{C}, 5 \% \mathrm{CO}_{2}$ incubator에서 20 시간 배양하였다. 세 포배양액을 제거한 후, 세포에 MTT를 $0.5 \mathrm{mg} / \mathrm{ml}$ 의 농도로 처리하여 4 시간 배양한 후, 배지를 제거하고 생성된 formazan crystals을 DMSO에 녹여 ELISA microplate reader (Tecan, USA)로 $570 \mathrm{~nm}$ 에서 흡광도를 측정하여 세포의 생존율을 구 하였다. 세포의 생존율은 control cell에 대한 백분율로 표시하 였다.

\section{Nitric oxide (NO) 생성량 측정}

RAW264.7 cell을 96 well plate에 $1 \times 10^{5}$ cells/well로 분주 하여 16시간 배양한 후, ATX를 농도별 $(25-100 \mu \mathrm{M})$ 로 처리하 여 1 시간 동안 배양하였다. 그 후, $\mathrm{LPS}$ 로 처리하여 $37^{\circ} \mathrm{C}, 5 \%$ $\mathrm{CO}_{2}$ incubator에서 20시간 배양하고, $\mathrm{NO}$ 의 양을 Griess 시약 으로 측정하였다. 즉, 세포배양액 $100 \mu 1$ 와 Griess 시약 $(1 \%$ sulfanilamide in $5 \%$ phosphoric acid $+1 \%$ a-naphthylamide in $\left.\mathrm{H}_{2} \mathrm{O}\right) 100 \mu 1$ 를 혼합하여 96 well plate에서 15 분 동안 반응시킨 후, $540 \mathrm{~nm}$ 에서 ELISA microplate reader (Tecan, USA)로 흡 광도를 측정하였다. Sodium nitrite $\left(\mathrm{NaNO}_{2}\right)$ 로 흡광도를 측정 하여 표준곡선을 얻은 후, $\mathrm{NO}$ 의 농도를 산출하였다.

\section{Immunoblot analysis}

$1 \%$ Triton X-100, $137 \mathrm{mM}$ sodium chloride, 10\% glycerol, $2 \mathrm{mM}$ EDTA, $1 \mathrm{mM}$ sodium orthovanadate, $25 \mathrm{mM}$ b-glycerophosphate, $2 \mathrm{mM}$ sodium pyrophosphate, $1 \mathrm{mM}$ phenylmethylsulfonylfluoride, $20 \mathrm{mM}$ Tris- $\mathrm{HCl}(\mathrm{pH}$ 7.5)와 1 $\mathrm{mg} / \mathrm{ml}$ leupeptin을 포함하는 buffer를 이용하여 cell을 lysis 
하였고, cell lysates를 $10,000 \times g$ 로 10 분간 원심분리하여 debris를 제거하였다. Inducible nitric oxide synthase (iNOS) 발 현은 anti-iNOS antibody를 사용하여 면역화학적 방법으로 분 석하였으며, anti-NF-kB p65 monoclonal antibody를 사용하 여 NF-kB를 측정하였다. 2차 antibody로는 goat anti-mouse IgG-horseradish peroxidase (HRP)를 사용하였으며, iNOS와 $\mathrm{NF}-\mathrm{kB}$ 의 band는 ECL immuno blotting detection reagents (Amersham)를 이용하여 발색하였다.

\section{핵 분획제조}

세포를 냉각시킨 $\mathrm{PBS}$ 로 2회 세척하고, 이것을 $\mathrm{PBS}$ 와 함께 microtube에 넣어 2,000× $g$ 로 5 분간 원심분리한 후, $\mathrm{PBS}$ 를 제 거하고, $10 \mathrm{mM}$ HEPES (pH 7.9), $10 \mathrm{mM} \mathrm{KCl}, 0.1 \mathrm{mM}$ EDTA, $0.5 \%$ Nonidet P-40, $1 \mathrm{mM}$ DTT, $0.5 \mathrm{mM}$ phenylmethylsulfonylfluoride를 함유하는 hypotonic buffer를 넣어 10 분간 얼음위에 놓은 후, $7,200 \times g$ 로 5 분간 원심분리하였다. 그 후, 상등액을 제거하고 crude nuclei가 함유된 pellet에 20 mM HEPES (pH 7.9), $400 \mathrm{mM} \mathrm{NaCl}, 1 \mathrm{mM}$ EDTA, $10 \mathrm{mM}$ DTT, $1 \mathrm{mM}$ PMSF를 함유하는 추출용 buffer $50 \mu \mathrm{l}$ 를 넣어 30 분간 얼음 위에 방치한 후, 10 분간 $15,800 \times g$ 로 원심분리하 여 핵분획이 포함된 상등액을 얻어 실험에 이용하였다.

\section{Cytokine 측정}

96 well plate에 세포 $\left(5 \times 10^{5} \mathrm{cells} / \mathrm{ml}\right)$ 를 분주하여 16 시간 동안 배양한 후, ATX를 농도별 $(25-100 \mu \mathrm{M})$ 로 1시간 처리한 후, $\mathrm{LPS}$ 로 처리하여 $37^{\circ} \mathrm{C}, 5 \% \mathrm{CO}_{2}$ incubator에서 20 시간 배양 하였다. 세포배양액 안에 존재하는 IL-6와 TNF-a 생성량을 ELISA Kit (Pierce Endogen, Rockford, IL, USA)를 사용하여 측정하였다.

Reporter constructs, transfection, reporter cell line, and luciferase assay

NGL cell $\left(5 \times 10^{5}\right.$ cells $\left./ \mathrm{ml}\right)$ 를 16 시간 배양한 후, ATX를 농도 별 $(25-100 \mu \mathrm{M})$ 로 1 시간 처리한 후 LPS $(1 \mu \mathrm{gg} / \mathrm{ml})$ 로 처리하고 24시간 동안 배양한 후, cell을 분리하여 Promega luciferase assay system (Promega, Madison, CA, USA)과 luminometer (Tecan, USA)를 이용하여 luciferase activity를 측정하였다. NF-kB 매개된 luciferase activity를 총 cell lysates의 단백질함 량으로 표준화하였고, 단백질의 양은 BCA protein assay kit (Pierce, Rockford, IL, USA)로 측정하였다.

\section{Superoxide radical scavenging activity assay}

Superoxide radical $\left(\mathrm{O}_{2}{ }^{-}\right)$scavenging activity assay는 산소 라디칼의 제거능을 확인하는 실험법으로 PMS-NADH superoxide generating system을 이용하였다. 즉, Nitroblue tetrazolium (NBT, $156 \mu \mathrm{M}) 1 \mathrm{ml}$ 와 $\beta$-nicotinamide adenine dinu- cleotide hydrate (NADH, $468 \mu \mathrm{M}) 1 \mathrm{ml}$ 를 혼합하고, positive control과 각 농도의 시료를 $1 \mathrm{ml}$ 씩 넣어 교반한 후, $1 \mathrm{ml}$ 의 phenazine methosulfate (PMS, $60 \mu \mathrm{M})$ 를 넣고 $25^{\circ} \mathrm{C}$ 에서 5 분 간 배양한 후, $560 \mathrm{~nm}$ 에서 absorbance를 측정하였다.

\section{$\mathrm{ROS}$ 생성측정}

RAW264.7 cell 내에 생성되는 산소라디칼 ROS를 측정하기 위하여 $2^{\prime}, 7^{\prime}$-dichloro-dihydrofluorescin diacetate (DCFH$\mathrm{DA})$ 를 이용하였다. 세포에 ATX를 농도별로 1 시간 처리한 후, LPS $(10 \mu \mathrm{g} / \mathrm{ml})$ 를 이용하여 24시간 동안 oxidative stress를 유발시켰다. 원심분리를 이용하여 pellet을 수집한 후, cell lysis buffer를 이용하여 시료를 추출해 실험에 이용하였다. 190 $\mu \mathrm{l}$ 의 PBS와 $50 \mu \mathrm{l}$ 의 $125 \mu \mathrm{M}$ DCFH-DA와 $10 \mu \mathrm{l}$ 의 시료를 96 well plate (black)에 넣고 잘 혼합하여 30분 동안 배양하였으 며 그 후, fluorescence spectrophotometer (Tecan, USA)를 이 용하여 $\mathrm{Ex}: 485 \mathrm{~nm}$ 와 $\mathrm{Em}: 530 \mathrm{~nm}$ 에서 측정한 후, $\mathrm{ROS}$ 생성수 준을 fluorescence/mg protein으로 계산하였다. 시료의 protein 함량은 BCA protein assay를 이용하여 측정하였다.

\section{통계학적 분석}

모든 실험결과는 3 회 이상 실험을 반복하여 얻은 자료를 이용하여 평균 \pm 표준편차로 나타내었고 통계학적 분석에는 SPSS version 14.0 을 이용하였다. 실험 군 간 비교에는 one-way analysis of variance (ANOVA) 및 independent $t$-test를 이용하였고, $p \times 0.05$ 를 통계학적으로 유의성이 있는 것 으로 간주하였다.

\section{결 과}

ATX가 LPS로 유도된 NO 생성에 미치는 효과 및 세포생 존율

RAW264.7 cell을 이용하여 LPS로 유도된 NO 생성에 대한 $\mathrm{ATX}$ 의 억제효과를 측정하였다. 대조군과 비교할 때, LPS군 $(10 \mu \mathrm{g} / \mathrm{ml}, 20 \mathrm{hr})$ 은 약 36 배의 $\mathrm{NO}$ 생성이 증가하였으며, ATX 처리군(25-100 $\mu \mathrm{M})$ 은 농도의존적으로 LPS로 유도된 NO의 생 성을 유의성 있게 억제하였다[25-100 $\mu \mathrm{M}(p<0.01)]$ (Fig. 1). 또 한, ATX의 세포독성효과를 MTT 방법을 이용하여 측정한 결 과, 세포생존율은 $100 \mu \mathrm{M}$ 의 농도에 이르기까지 영향을 받지 않았다(Fig. 2).

\section{ATX가 LPS로 유도된 iNOS 단백질 발현억제에 미치는 효과}

$\mathrm{ATX}$ 를 이용하여 염증인자 $\mathrm{NO}$ 의 생성억제와 $\mathrm{iNOS}$ 단백질 발현억제와의 상관관계를 알아보기 위하여 immunoblot analysis로 단백질발현을 조사한 결과, LPS에 반응한 $\mathrm{iNOS}$ 단백질 은 현저하게 증가하였으며, ATX는 50 및 $100 \mu \mathrm{M}$ 의 농도에서 


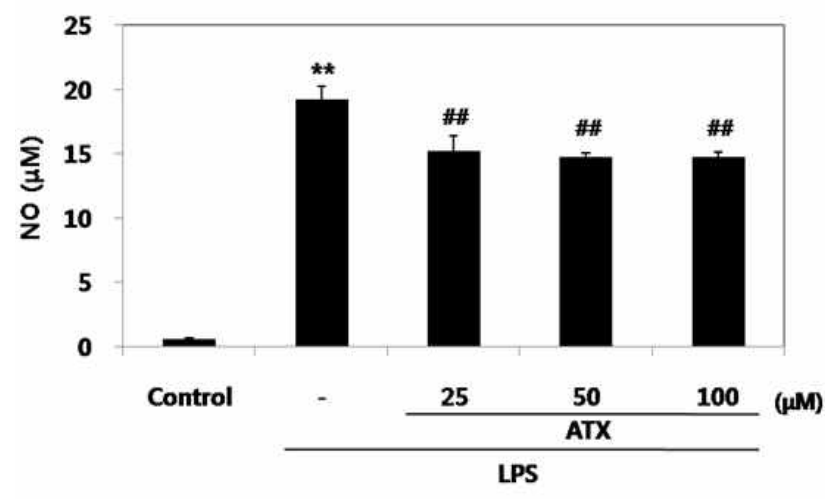

Fig. 1. Inhibitory effects of ATX on NO production by LPS. The RAW264.7 cells $\left(5 \times 10^{5}\right.$ cells $\left./ \mathrm{ml}\right)$ were treated with various concentrations of ATX for $1 \mathrm{hr}$ prior to the addition of LPS $(10 \mu \mathrm{g} / \mathrm{ml})$, and then the cells were further incubated for $20 \mathrm{hr}$. Control cells were incubated with vehicle alone. The concentrations of $\mathrm{NO}$ in culture medium were monitored as described in the methods section. Data represent the mean $\pm S D$ from three separate experiments. ${ }^{* *} p<0.01$, significant compared with vehicle-treated control; ${ }^{\# \#} p<0.01$, significant compared with LPS alone.

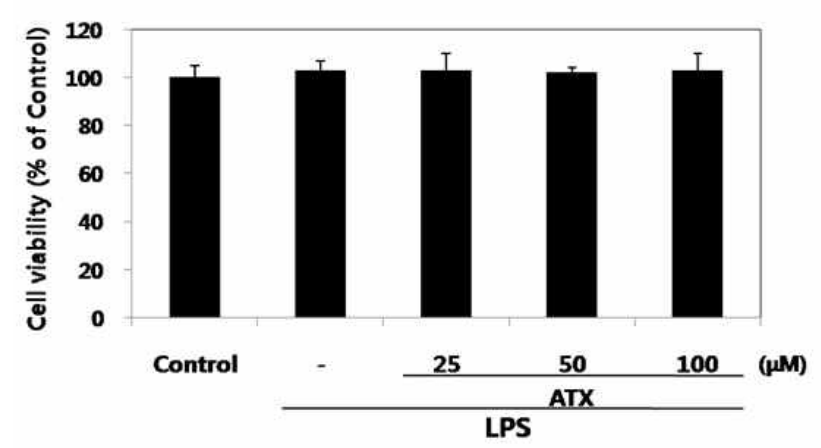

Fig. 2. Cytotoxic effects of ATX in RAW264.7 cells. The cytotoxic effects of ATX in cells were determined by MTT assay. Cells $\left(2.5 \times 10^{5}\right.$ cells $\left./ \mathrm{ml}\right)$ were treated with various concentrations of ATX for $1 \mathrm{hr}$ prior to the addition of LPS $(10 \mu \mathrm{g} / \mathrm{ml})$, and then the cells were further incubated for $20 \mathrm{hr}$. Control cells were incubated with vehicle alone. Three independent experiments were performed, and data shown represent the mean \pm SD.

iNOS 단백질발현을 억제하였다(Fig. 3). 이는 ATX에 의한 NO 생성의 감소가 $\mathrm{iNOS}$ 단백질발현의 조절에 의한 것임을 나타 낸다.

\section{ATX가 LPS로 유도된 $\| \mathrm{L}-6$ 및 $\mathrm{TNF}-\mathrm{a}$ 의 생성에 미치는 효과}

LPS로 유도된 IL-6 및 TNF-a의 생성에 대한 ATX의 억제효 과는 enzyme immunoassay 방법을 이용하여 확인하였으며

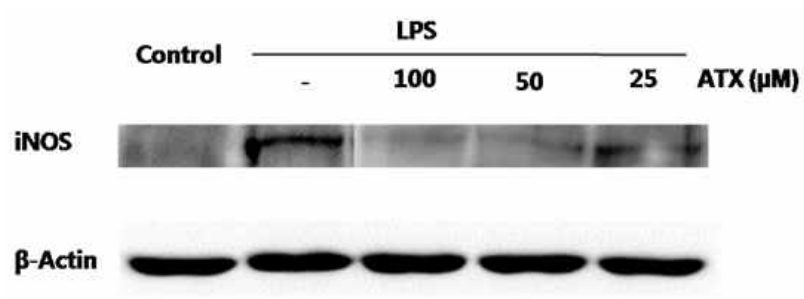

Fig. 3. Inhibitory effects of ATX on iNOS induction by LPS. The RAW264.7 cells $\left(5 \times 10^{5}\right.$ cells $\left./ \mathrm{ml}\right)$ were treated with concentrations of ATX (25, 50 and $100 \mu \mathrm{M})$ for $1 \mathrm{hr}$ prior to the addition of LPS $(10 \mu \mathrm{g} / \mathrm{ml})$, and then the cells were further incubated for $20 \mathrm{hr}$. Control cells were incubated with vehicle alone. The protein levels of iNOS were determined by immunoblot analysis. $\beta$-Actin was used as a loading control.

LPS 처리군 $(10 \mu \mathrm{g} / \mathrm{ml}, 20 \mathrm{hr})$ 은 대조군과 비교해 약 11 배의 IL-6 $(p<0.05)$ 및 약 23배의 TNF-a $(p<0.01)$ 를 생성함으로 유의 성 있는 증가를 보였다. 또한 LPS로 유도된 IL-6 및 TNF-a 생성에 대한 $\mathrm{ATX}$ 의 억제효과가 $100 \mu \mathrm{M}$ 의 ATX 농도에서 모 두 유의성 있게 $(p<0.05)$ 나타났다. 특히, 이 농도에서 ATX는 LPS로 유도된 IL-6의 생성을 $65.2 \%$ 억제시켰고, TNF-a의 생성 을 $21.2 \%$ 억제시킴으로 IL-6에 있어 약 3 배 더 높은 억제효과 를 보였다(Fig. 4).

ATX가 LPS로 유도된 $\mathrm{NF}-\kappa \mathrm{B}$ transcriptional activity 에 미치는 효과

ATX가 LPS로 유도된 NF- $\kappa B$ transcriptional activity에 미 치는 영향을 조사하였다. NF-kB reporter construct로 transfection된 RAW264.7 cell인 NGL cell을 ATX의 유무 하에 10 $\mu \mathrm{g} / \mathrm{ml}$ 의 LPS로 처리하여 실험을 진행하였다. ATX 처리군 (25-100 $\mu \mathrm{M})$ 은 용량 의존적으로 LPS로 유도된 NF- kB transcriptional activity를 억제하였다. 특히, $100 \mu \mathrm{M}$ 의 ATX 처리 는 NF- $\kappa \mathrm{B}$ transcriptional activity (NF- $\kappa \mathrm{B}$ dependent luciferase activity)를 유의성 있게 감소시켰다(Fig. 5). 이는 $100 \mu \mathrm{M}$

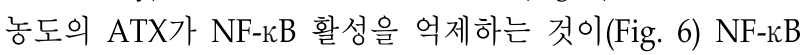
transcriptional activity의 억제와 연계됨을 의미한다.

\section{ATX가 LPS로 유도된 NF- $\mathrm{KB}$ 활성에 미치는 효과}

$\mathrm{ATX}$ 가 LPS로 유도된 NF- $\mathrm{kB}$ 활성에 미치는 영향을 알아보 기 위하여 immunoblot analysis로 NF-kB (p65 subunit)의 발 현수준을 조사하였다. Kim 등[14]은 NF- $\mathrm{kB}$ 가 LPS 처리 후 30-60분에 활성화 되었다고 보고하였으며, 본 실험도 동일한 양상을 나타내었다. LPS 처리 후, 30 및 60 분에서 NF-kB 활성 이 나타났으며, $100 \mu \mathrm{M}$ 의 ATX 처리로 억제되었다(Fig. 6). 이 결과는 $\mathrm{ATX}$ 가 NF-kB 활성을 억제한다는 것을 나타내며, 이는 $\mathrm{ATX}$ 가 $\mathrm{I} \kappa \mathrm{Ba}$ 분해를 저해하여 NF- $\mathrm{kB}$ 가 핵으로 전위하는 것을 억제함을 의미한다. 
(A)

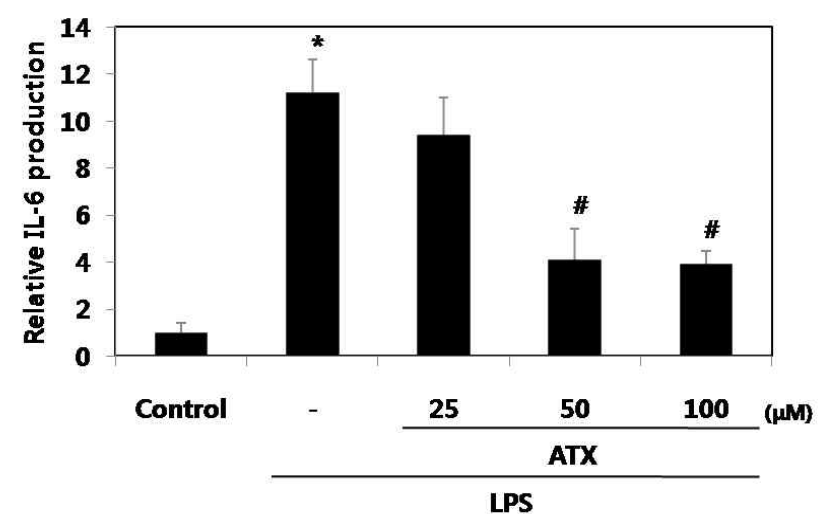

(B)

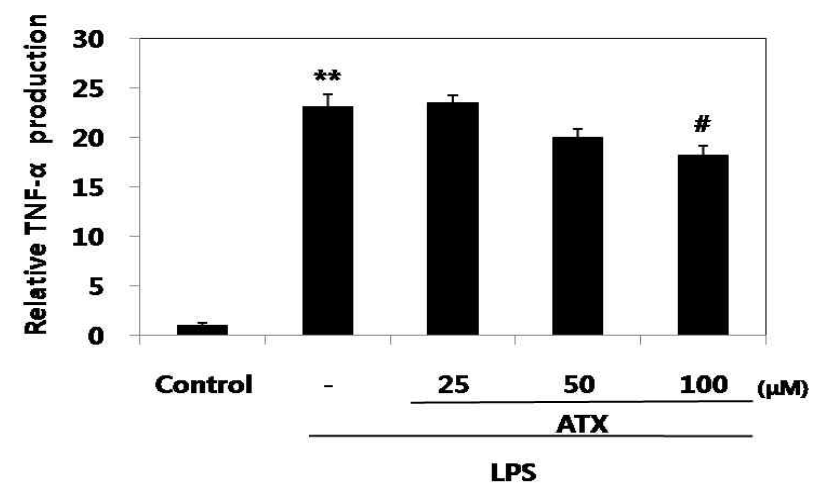

Fig. 4. The inhibitory effects of ATX on LPS-induced production of proinflammatory cytokines (IL-6 and TNF-a) in RAW264.7 cells. The cells $\left(5 \times 10^{5}\right.$ cells $\left./ \mathrm{ml}\right)$ were treated with various concentrations of ATX for $1 \mathrm{hr}$ prior to the addition of LPS $(10 \mu \mathrm{g} / \mathrm{ml})$, and then the cells were further incubated for $20 \mathrm{hr}$. Control cells were incubated with vehicle alone. The levels of proinflammatory cytokines were measured by ELISA (A and B). Data represent the mean $\pm \mathrm{SD}$ from three separate experiments. ${ }^{*}<<0.05$, ${ }^{* *} p<0.01$, significant compared with vehicle-treated control; ${ }^{*} p<0.05$, significant compared with LPS alone.

Superoxide radical 소거활성에 의한 ATX와 $a^{-}$ tocopherol의 항산화효능 비교

비효소적 superoxide radical 생성계인 NADH/PMS에서 superoxide radical의 소거능은 ATX의 경우 $0.01-5 \mathrm{mg} / \mathrm{ml}$ 의 농도에서 농도 의존적으로 소거되는 경향을 나타내었으며, positive control인 a-tocopherol에서도 동일한 양상을 나타내 었다. 또한 $5 \mathrm{mg} / \mathrm{ml}$ 의 농도에서 ATX는 a-tocopherol에 비해 superoxide radical 소거능이 1.33배 더 높았다(Fig. 7).

\section{$\mathrm{ROS}$ 의 생성에 미치는 $\mathrm{ATX}$ 의 효과}

$\mathrm{ATX}$ 의 항산화작용(Fig. 7)이 세포 내에서 발생하는 ROS 수준에 있어서도 동일한 양상을 나타내는 지를 조사하기 위해 대식세포인 RAW264.7 cell을 이용하여 실험을 수행하였다.

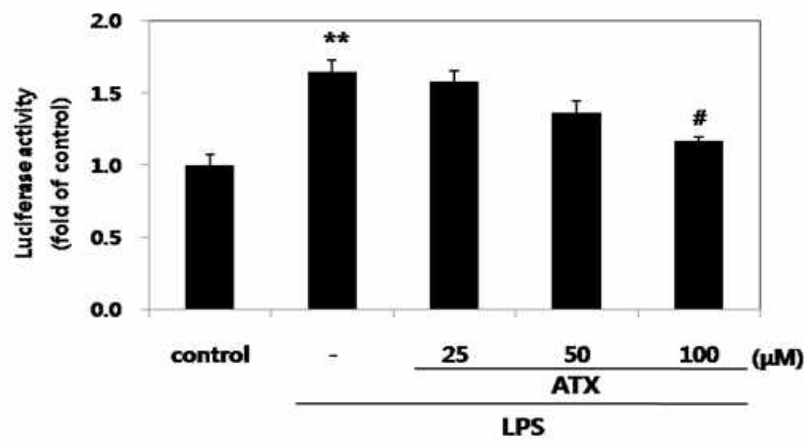

Fig. 5. Inhibitory Effects of ATX on LPS-Induced NF- $\kappa B$ Transcriptional Activity. RAW264.7 cells were transfected with an NF- $\kappa B$ reporter construct as described in the methods section and then either untreated (control) or pretreated with different concentrations (25-100 $\mu \mathrm{M})$ of ATX for $1 \mathrm{hr}$. LPS $(10 \mu \mathrm{g} / \mathrm{ml})$ was then added and cells were further incubated for $24 \mathrm{hr}$. Cells were then lysed and luciferase activities were determined using a Promega luciferase assay system and a luminometer. Data represent the mean $\pm S D$ from three separate experiments. ${ }^{* *} \not<0.01$, significant compared with vehicle-treated control; ${ }^{\#} p<0.05$, significant compared with LPS alone.

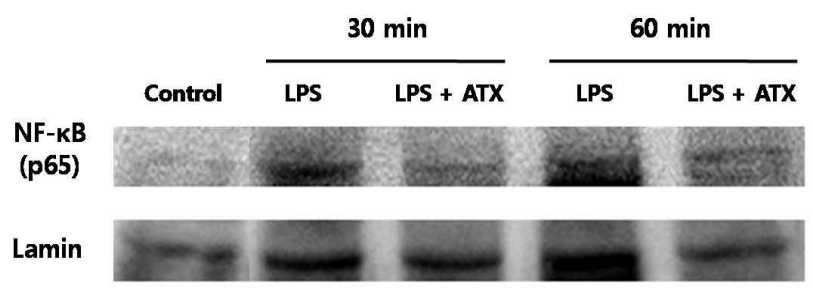

Fig. 6. The inhibitory effects of ATX on NF-kB (p65 subunit) activation by LPS. The RAW264.7 cells $\left(5 \times 10^{5}\right.$ cells $\left./ \mathrm{ml}\right)$ were treated with ATX $(100 \mu \mathrm{M})$ for $1 \mathrm{hr}$ prior to the addition of LPS $(10 \mu \mathrm{g} / \mathrm{ml})$, and then the cells were further incubated for 30 and $60 \mathrm{~min}$. Control cells were incubated with vehicle alone. Nuclear extracts for NF- $\kappa B$ were prepared as described in the methods section. The protein levels of NF-kB were determined by immunoblot analysis. Lamin A/C was used as a loading control.

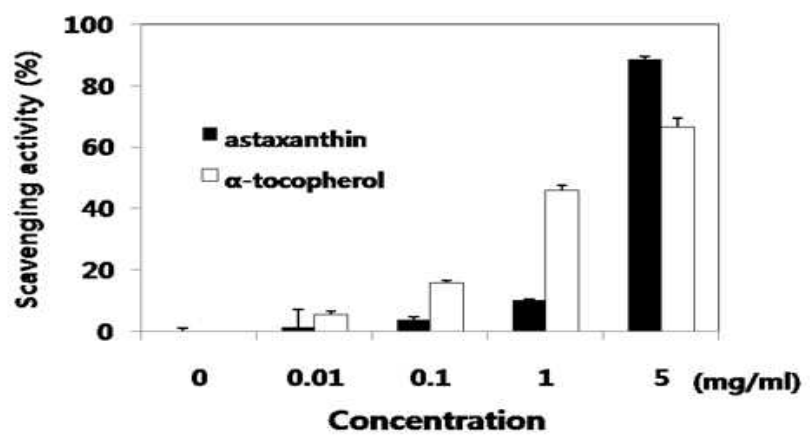

Fig. 7. Superoxide radical scavenging activity of astaxanthin and a-tocopherol. Data represent the mean $\pm S D$ from three separate experiments. 


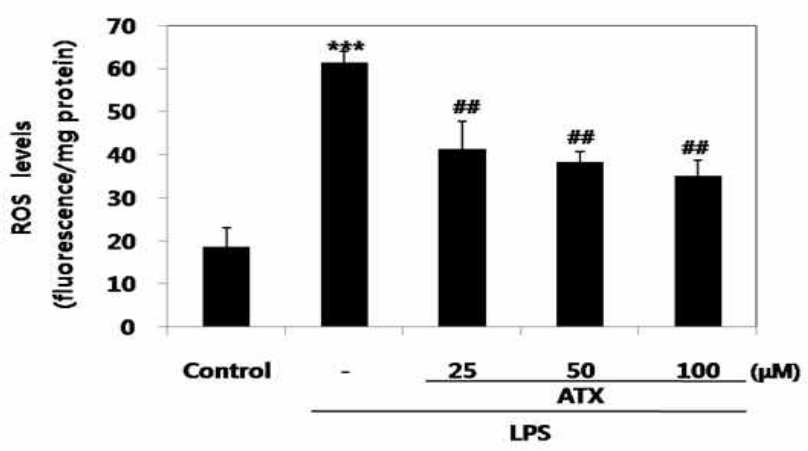

Fig. 8. Effects of ATX on ROS generation. RAW264.7 cells were treated with various concentrations of ATX $(25-100 \mu \mathrm{M})$ for $1 \mathrm{hr}$ prior to the addition of LPS $(10 \mu \mathrm{g} / \mathrm{ml})$, and then the cells were further incubated for $24 \mathrm{hr}$. Control cells were incubated with vehicle alone. Cell lysates were incubated with DCFH-DA for $30 \mathrm{~min}$ and intracellular levels of ROS were measured by fluorescence spectrophotometer (Ex: 485 nm; Em: $530 \mathrm{~nm}$ ). Data represent the mean $\pm S D$ from three separate experiments. ${ }^{* * *} p<0.001$, significant compared with vehicle-treated control; ${ }^{\# \#} p<0.01$, significant compared with LPS alone.

LPS 처리군은 대조군에 비해 약 3.3배의 ROS 생성량이 증가하 였으며, 이러한 ROS의 증가는 ATX에 의해 농도 의존적으로 억제되었다(Fig. 8). 즉, ATX 처리군(25-100 $\mu \mathrm{M})$ 은 농도의존적 으로 LPS로 유도된 ROS 생성을 유의성 있게 억제하였다 $(p<0.01)$.

\section{고 찰}

염증, 자가면역질환, 암, 노화, 뇌혈관질환, 심혈관계질환 등 의 원인이 ROS인 free radical (hydroxyl 및 peroxyl radicals) 및 singlet oxygen 생성에 관련이 있다는 사실이 밝혀짐에 따 라 항산화 효능을 가지는 식품의 섭취를 통해 노화를 지연시 키고, 여러 가지 질병을 예방 및 치료하고자 하는 노력이 증가 하고 있다. 이러한 질병들을 일으키는 ROS는 매우 불안정하 고 반응성이 아주 강해 세포내 단백질, 당 및 지방산은 물론이 고, 유전정보를 함유한 DNA 까지도 산화적 손상을 입히며, 결과적으로 이러한 손상은 세포에 치명적인 피해를 입혀 세포 가 기능을 잃거나 암세포로 변형되는 것으로 알려져 있다 $[10,28]$.

$\mathrm{NO}$ 는 세포 내에서 다양하게 작용한다. 즉, $\mathrm{CNOS}$ 는 일정한 양의 $\mathrm{NO}$ 를 생산하므로 신경시스템에서 신호전달을 위해 작 용을 하거나 혹은 혈관을 확장하여 혈압을 조정하므로 세포의 항상성에 기여한다. 반면에, $\mathrm{iNOS}$ 는 LPS로 처리된 대식세포 에서 많은 양의 $\mathrm{NO}$ 를 생성하므로 세포에 손상을 초래하며 [33], 다양한 급성 및 만성적 염증상황에서 병리학적인 과정에 관여 할 수 있다[13]. 생성된 NO 양을 Griess 시약으로, iNOS 단백질발현을 immunoblot으로 분석한 결과, ATX는 LPS로
유도된 NO 생성 및 $\mathrm{iNOS}$ 단백질발현 수준을 현저히 억제시 켰다. 이는 ATX가 iNOS의 기능을 제어하여 NO 생성을 감소 시키므로 신경질환[2]을 포함하는 염증성 질병의 치료에 이용 될 수 있을 것으로 사료된다.

염증성 cytokine인 IL-6와 TNF-a는 면역학적 기능이 다양 할 뿐 아니라 target cell과 상호작용을 하며[6] 염증을 매개하 고 조절한다. 또한, 다른 면역세포들을 활성화시키고 류마티 스성 관절염 같은 염증성 질병을 일으킬 수 있다[11]. 특히, IL-6는 주로 단핵구나 대식세포에서 분비되며 증식하는 B 세 포가 형질세포로 전환되는 마지막 분화단계를 증진시키고, 항 체분비를 자극하는 것으로, 이 cytokine의 수준은 염증성 병변 에서 항상 증가하는 것으로 보고되고 있다[7]. 최근에, 약초들 의 추출성분을 이용하여 IL-6 및 TNF-a [15]와 같은 염증성 사이토카인을 억제시킴으로 염증성 질환을 치료하는 새로운 연구영역이 확대되고 있다. LPS로 대식세포를 자극하면 많은 양의 IL-6 및 TNF- $a$ 가 방출되며, 이러한 cytokine들에 대한 $\mathrm{ATX}$ 의 억제효과를 ELISA kit을 이용하여 측정하였다. LPS는 IL-6 및 TNF-a의 생성을 유의성 있게 증가시켰으며, ATX (100 $\mu \mathrm{M})$ 는 LPS로 유도된 IL-6 및 TNF- $a$ 의 생성을 유의성 있게 억제시켰다. 특히, 이 농도에서 ATX는 LPS로 유도된 IL-6 및 TNF-a 생성을 각각 $65.2 \%, 21.2 \%$ 억제시킴으로 IL-6에 있어 약 3 배 더 높은 억제효과를 보였다.

$\mathrm{NF}-\kappa \mathrm{B}$ 는 면역반응, 세포자살 및 cell cycle에 관련된 유전자 발현을 조절하는 편재된 전사인자이며, $\mathrm{iNOS}, \mathrm{COX}-2, \mathrm{IL}-1 \beta$ 및 TNF- $a$ 를 포함하는 많은 염증성 유전자들의 발현을 조절한 다[23]. 그리고 이 전사인자의 비정상적인 활성은 다양한 염증 성질병과 종양생성에 관련되며, 항염증 약제들은 NF-kB 경로 를 조절할 수 있다[5]. 또한 이 전사인자의 활성화를 억제하는 것은 암과 염증성질병의 예방과 치료에 효과적인 것으로 보고 되었다[1]. NO, IL-6 및 TNF-a를 억제하는 분자적인 기작을 이해하기 위해 LPS로 유도된 NF- $\mathrm{KB}$ 활성에 대한 ATX의 효능 을 immunoblot으로 분석한 결과, ATX가 LPS로 유도된 NF-k $\mathrm{B}$ 활성을 효과적으로 억제하였다. 이러한 결과는 ATX가 LPS 로 유도된 대식세포에서 NF-kB 경로를 조절할 수 있다는 것을 의미한다. NF-kB 경로는 iNOS 발현의 조절에 관련되며, 몇몇 화학방어적인 phytochemicals는 과도한 이 전사인자의 활성 을 억제하므로 iNOS 발현을 억제한다[32]. 또한 이 경로는 LPS로 자극된 세포에서 염증성 cytokine들의 방출을 조절하 는 핵심 조정자이다[20]. 더욱이 NF-kB dependent luciferase assay로 측정한 결과, ATX $(100 \mu \mathrm{M})$ 는 LPS로 유도된 luciferase 활성을 현저히 억제하였다. 결과를 종합해 볼 때, ATX로 $\mathrm{NF}-\kappa \mathrm{B}$ transcriptional activity를 억제시키는 것이 NF- $\mathrm{kB}$ 의 활성억제와 연계됨을 시사한다. 이러한 현상은 iNOS, IL-6, TNF-a 및 ROS의 유도에 대한 억제와 밀접하게 관련되어 있 다. 이는 ATX가 NF- $\mathrm{BB}$ p65 subunit의 핵 전위 및 $\mathrm{I} \kappa \mathrm{Ba}$ 의 분해 를 억제하여 염증성 매개자들의 생성을 저해한다는 Lee 등 [22]의 보고와 일치한다. 
Superoxide radical은 산소분자가 한 개의 전자에 의해 환 원된 형태를 가진 것이며, 대부분의 산화반응은 이 radical이 생성되는 반응경로와 긴밀히 연관되어 있다. 또한 이 radical 은 항상 과산화수소와 산소를 생성하게 하는 반응 중간체로서 작용하여 다양한 다른 활성산소 화학종들의 생성과 직접 관련 되어 있다. 더욱이 활성산소의 일종인 이 radical은 DNA를 손상시켜 류마티스성 관절염, 동맥경화증, 심근경색증 및 암 을 유발 할 수 있고[25], 또한 생물체의 노화와의 관련성이 보 고되고 있다[8]. ATX가 superoxide radical과 반응하여 이를 얼마나 감소시키는 지를 조사한 결과, $5 \mathrm{mg} / \mathrm{ml}$ 의 ATX가 동 일농도의 a-tocopherol에 비해 superoxide radical 소거능이 더욱더 높은 것으로 나타났으며, 이는 ATX가 강력한 항산화 제인 a-tocopherol 보다 더 우수한 항산화제라는 것을 의미한 다. 또한, Ma와 Kinneer [24]는 LPS로 유도된 NF- $\mathrm{kB}$ 활성이 phenolic antioxidants에 의해 억제된다고 보고하였다. 이는 항산화제가 세포의 신호전달체계에서 항염증제와 거의 같은 역할을 담당할 수도 있다는 것을 시사한다. DCFH-DA를 이용 한 $\mathrm{ROS}$ 측정결과, $\mathrm{ATX}$ 는 세포내부의 $\mathrm{ROS}$ 축적을 강력하게 제거하였다. 이러한 ATX의 항산화효능이 NF-kB 활성을 억제 시키는 이 물질의 항염증효능과 상호 깊은 연관성이 있을 것 으로 사료된다. 또한 Sanlioglu 등[30]은 세포내부의 ROS 증가 가 $\mathrm{IKK}$ 의 활성을 높혀 NF-kB 활성을 증가시킨다고 보고하였 다. 그러므로 ROS는 NF- $\mathrm{kB}$ 의 활성화 및 NO, IL-6, TNF-a 등 의 생성에 있어 중요한 원천물질일 가능성이 있다.

결론적으로, 미세조류 유래 생리활성물질인 ATX가 우수한 superoxide radical 소거제이며, LPS로 유도된 대식세포에서 $\mathrm{ROS}$ 의 생성 및 NF- $\mathrm{NB}$ 활성을 저해하므로 $\mathrm{iNOS}$ 의 발현 및 $\mathrm{NO}, \mathrm{IL}-6, \mathrm{TNF}-\mathrm{a}$ 의 생성이 억제됨을 확인 할 수 있었다. 따라 서 ATX를 이용한 항염증제, 항산화제 및 항암치료제 등의 개 발가능성을 제시한다.

\section{감사의 글}

본 연구는 부산광역시 신성장산업과와 중소기업 산학연협 력 기업부설연구소 설치지원사업의 지원을 받아 수행하였습 니다.

\section{References}

1. Aggarwal, B. B. 2004. Nuclear factor-kB: The enemy within. Cancer Cell 6, 203-208.

2. Albina, J. L. and J. S. Reichner. 1998. Role of nitric oxide mediation of macrophage cytotoxicity and apoptosis. Cancer Metast Rev. 17, 39-53.

3. Bendich, A. 1991. Non vitamin a activity of carotenoids: immuno enhancement. Food Sci. Technol. Res. 2, 127-130.

4. Bennedsen, M., X. Wang, R. Willen, T. Wadstrom, and L. P. Andersen. 1999. Treatment of H. pylori infected mice with antioxidant astaxanthin reduces gastric inflammation, bacterial load and modulates cytokine release by splenocytes. Immunol. Lett. 70, 185-189.

5. Berg, J., H. Fellier, T. Christoph, J. Grarup, and D. Stimmeder. 1999. The analgesic NSAID lornoxicam inhibits cyclooxygenase (COX)-1/-2, inducible nitric oxide synthase (iNOS), and the formation of interleukin (IL)-6 in vitro. Inflamm Res. 48, 369-379.

6. Beutler, B. and A. Cerami. 1989. The biology of cachectin/TNF-a primary mediator of the host response. Annu. Rev. Immunol. 7, 625-655.

7. Delgado, A. V., A. T. McManus, and J. P. Chambers. 2003. Production of Tumor Necrosis Factor-alpha, Interleukin 1-beta, Interleukin 2, and Interleukin 6 by rat leukocyte subpopulations after exposure to Substance P. Neuropeptides 37, 355-361.

8. Fridovich, I. 1997. Superoxide anion radical, superoxide dismutases, and related matters. J. Biol. Chem 272, 18515-18517.

9. Ghosh, S. and M. Ksarin. 2002. Missing pieces in the NF- $\kappa B$ puzzle. Cell 109, S81-S96.

10. Guerin, M., M. E. Huntley, and M. Olaizola. 2003. Haematococcusastaxanthin: applications for human health and nutrition. Trends Biotechnol. 21, 210-216.

11. Guslandi, M. 1998. Nitric oxide and inflammatory bowel diseases. Eur. J. Clin. Invest. 28, 904-907.

12. Guzik, T. J. and K. M. Channon. 2005. Measurement of vascular reactive oxygen species production by chemiluminescence. Method Mol. Med 108, 73-89.

13. Kilbourn, R. G. and P. Belloni. 1990. Endothelial cell production of nitric oxide in response to interferon- $\gamma$ in combination with tumor necrosis factor, interleukin-1, or endotoxin. J. Natl. Cancer Inst. 82, 772-776.

14. Kim, S. G., H. J. Kim, S. H. Choi, and J. Y. Ryu. 2000. Inhibition of lipopolysaccharide-induced I-kB degradation and tumor necrosis factor-expression by dimethyl-4, 40-dimethoxy-5, 6, 50, 60-dimethylene dioxybiphenyl-2,20-dicarboxylate (DDB): minor role in hepatic detoxifying enzyme expression. Liver 20, 319-329.

15. Kim, S. J., H. J. Jeong, P. D. Moon, K. M. Lee, H. B. Lee, H. J. Jung, S. K. Jung, H. K. Rhee, D. C. Yang, S. H. Hong, and H. M. Kim. 2005. Anti-inflammatoryactivity of gumiganghwaltang through the inhibition of nuclear factor-kappa B activation in peritoneal macrophages. Biol. Pharm Bull. 28, 233-237.

16. Kim, Y. W., R. J. Zhao, S. J. Park, J. R. Lee, I. J. Cho, C. H. Yang, S. G. Kim, and S. C. Kim. 2008. Anti-inflammatory effects of liquiritigenin as a consequence of the inhibition of NF-kB-dependent iNOS and proinflammatory cytokines production. Brit. J. Pharmacol. 154, 165-173.

17. Krinsky, N. I. 1989. Antioxidant functions of carotenoids. Free Radical Bio. Med 7, 617-635.

18. Kurashige, M., E. Okimasu, M. Inoue, and K. Utsumi. 1990. Inhibition of oxidative injury of biological membranes by astaxanthin. Physiol. Chem Phys. Med NMR. 22, 27-38.

19. Kurihara, H. 2002. Contribution of the antioxidative property of astaxanthin to its protective effect on the promotion of cancermetastasis in mice treated with restraint stress. Life 
Sci. 70, 2509-2520.

20. Lappas, M., M. Permezel, H. M. Georgiou, and G. E. Rice. 2002. Nuclear factor kappa B regulation of proinflammatory cytokines in human gestational tissues in vitro. Biol. Reproduct. 67, 668-673.

21. Lee, A. K., S. H. Sung, Y. C. Kim, and S. G. Kim. 2003. Inhibition of lipopolysaccharide-inducible nitric oxide synthase, TNF-alpha and COX-2 expression by sauchinone effects on I-kappa B alpha phosphorylation, C/EBP and AP-1 activation. Brit. J. Pharmacol. 139, 11-20.

22. Lee, S. J., S. K. Bai, K. S. Lee, S. Namkoong, H. J. Na, K. S. Ha, J. A. Han, S. V. Yim, K. Chang, Y. G. Kwon, S. K. Lee, and Y. M. Kim. 2003. Astaxanthin inhibits nitric oxide production and inflammatory gene expression by suppress-

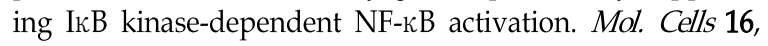
97-105.

23. Li, Q. and I. M. Verma. 2002. NF- $\mathrm{kB}$ regulation in the immune system. Nat. Rev. Immunol. 2, 725-734.

24. Ma, Q. and K. Kinneer. 2002. Chemo-protection by phenolic antioxidants.Inhibition of tumor necrosis factor- $a$ induction in macrophages. J. Biol. Chem 277, 2477-2484.

25. Miesel, R., M. P. Murphy, and H. Kroeger. 1996. Enhanced mitochondrial radical production in patients which rheumatoid arthritis correlates with elevated levels of tumor necrosis factor alpha in plasma. Free Radical Res. 25, 161-9.

26. Naguib, Y. M. A. 2000. Antioxidant activities of astaxanthin and related carotenoids. J. Agr. Food Chem 48, 1150-1154.

27. Palozza, P. and N. I. Krinsky. 1992. Astaxanthin and canthaxanthin are potent antioxidants in a membrane model. Arch
Biochem Biophys. 297, 291-295.

28. Papas, A. M. 1999. Antioxidant Status, Diet, Nutrition, and Health, CRC Press.

29. Rachmilewitz, D., J. S. Stamler, F. Karmeli, M. E. Mullins, D. J. Singel, J. Loscalzo, R. J. Xavier, and D. K. Podolsky. 1993. Peroxynitrite-induced rat colitis- a new model of colonic inflammation. Gastroenterology 105, 1681-1688.

30. Sanlioglu, S., C. M. Williams, L. Samavati, N. S. Butler, G. Wang, P. B. McCray, T. C. Jr.Ritchie, G. W. Hunninghake, E. Zandi, and J. F. Engelhardt. 2001. Lipopolysaccharide induces Rac1-dependent reactive oxygen species formation and coordinates tumor necrosis factor-a secretion through IKK regulation of NF-kB. J. Biol. Chem 276, 30188-30198.

31. Shimidzu, N., M. Goto, and W. Miki. 1996. Carotenoids as singlet oxygen quenchers in marine organisms. Fish Sci. 62, 134-137.

32. Surh, Y. J., K. S. Chun, H. H. Cha, S. S. Han, Y. S. Keum, K. K. Park, and S. S. Lee. 2001.Molecular mechanisms underlying chemopreventive activities of anti-inflammatory phytochemicals: down-regulation of COX-2 and iNOS through suppression of NF-kB activation. Mutat. Res. 480-481, 243-268.

33. Tomē, L. A., L. Yu, I. de Castro, S. B. Campos, and A. C. Seguro. 1999. Beneficial and harmful effects of L-arginine on renal ischaemia. Nephrol. Dial. Transpl. 14, 1139-1145.

34. Yonouchi, J. 1993. Astaxanthin enhances in vitro antibody production to T-dependent antigens without facilitating polyclonal B-cell activation. Nutr. Cancer 19, 269-280.

\title{
초록 : 미세조류 유래 astaxanthin의 항염증 및 항산화 효과
}

\author{
곽태원 ${ }^{1} \cdot$ 차지영 ${ }^{1} \cdot$ 이철원 ${ }^{2} \cdot$ 김영민 ${ }^{3} \cdot$ 유병홍 $^{3} \cdot$ 김성구 $^{3} \cdot$ 김종명 $^{4} \cdot$ 박성하 $^{1} \cdot$ 안원근, ${ }^{12}$ \\ ( ${ }^{1}$ 부산대학교 한의학전문대학원, ${ }^{2}$ 부산대학교 해양생물기술연구소, ${ }^{3}$ (주)바이오포트코리아, ${ }^{4}$ 부경대학교 수 \\ 산과학대학)
}

Astaxanthin (ATX)은 다양한 생명체에서 생성되는 카로티노이드 색소이다. 본 연구에서는 ATX가 RAW264.7 cell에서 LPS에 의한 inducible nitric oxide synthase (iNOS), nitric oxide (NO), 염증성 사이토카인, nuclear factor-kappa B (NF-kB)와 reactive oxygen species (ROS)의 생성을 억제 시키는 지 또한, superoxide radical 소거능 이 있는 지를 조사하였다. iNOS와 NF-kB는 immunoblot analysis로, interleukin (IL)-6와 tumour necrosis factora (TNF-a)는 ELISA 법으로 분석하였다. NO 양은 nitrite의 양을 측정하였고, ROS는 $2^{\prime}, 7^{\prime}$-dichlorodihydrofluorescin diacetate (DCFH-DA) 법으로 superoxide radical 소거능은 superoxide radical scavenging activity assay로 검증하였다. $100 \mu \mathrm{M}$ 의 ATX 농도에서 LPS로 유도된 NO, IL-6 및 TNF-a 같은 염증성 사이토카인의 생성 뿐만 아니라 iNOS 및 NF-kB의 발현도 억제되었다. 특히, IL-6 및 TNF-a 생성에 있어 ATX의 최대 억제율은 각각 $65.2 \%$ 및 $21.2 \%$ 이었으며 LPS로 유도된 NF-kB의 전사활성을 억제하였다. 이러한 현상은 세포질에서 핵으로 NF$\kappa \mathrm{B}$ 의 전위를 억제하는 것과 관련이 있다. 또한, 25-100 $\mu \mathrm{M}$ 의 ATX 농도에서 세포 내 ROS 생성을 억제하였으며, $5 \mathrm{mg} / \mathrm{ml}$ 농도의 ATX는 동일농도의 a-tocopherol에 비해 superoxide radical 소거능이 1.33배 높았다. 이러한 결 과들은 $\mathrm{ATX}$ 가 대식세포에서 ROS 생성 및 NF-kB 활성을 저해하므로 iNOS의 발현, NO 및 염증성 사이토카인의 생성을 억제하며, 또한 우수한 superoxide radical 소거능을 보유한다는 것을 나타내었다. 결론적으로, ATX가 항 염증제 및 항산화제로서 유용하게 사용될 수 있을 것으로 사료된다. 